Journal of Health Promotion and Behavior (2018), 3(2): 86-93

https://doi.org/10.26911/thejhpb.2018.03.02.01

\title{
Path Analysis: Factors Associated with Self Preventive Care among Patients with Type 2 Diabetes Mellitus in Surakarta
}

\author{
Ummy Prasetyowati'), Didik Tamtoto²), Bhisma Murti1) \\ 1)Masters Program in Public Health, Universitas Sebelas Maret \\ 2)Faculty of Medicine, Universitas Sebelas Maret
}

\begin{abstract}
Background: Patients with diabetes have an increased risk of morbidity and mortality from several conditions, such as cardiovascular, cerebrovascular, or kidney diseases and heart failure. In addition, economic analysis indicates that mean total costs associated with microvascular complications have almost doubled compared with those for patients without these complications. This study aimed to analyze factors associated with self preventive care among patients with type 2 diabetes mellitus in Surakarta, using a path analysis model.

Subjects and Method: A cross sectional study was conducted at Dr. Moewardi Hospital, Surakarta, Central Java, from March to April 2018. A sample of 200 type DM patients was selected by total sampling. The dependent variable was self preventive care. The independent variables were perceived severity, susceptibility, threat, benefit, cues to action, self efficacy, attitude, and family support. The data were collected by questionnaire and analyzed by path analysis.

Results: Self preventive care directly increased with perceived threat $(b=3.21 ; 95 \% \mathrm{CI}=1.98$ to 4.44; $\mathrm{p}<0.001)$, perceived benefit $(\mathrm{OR}=0.68 ; 95 \% \mathrm{CI}=-0.11$ to $1.47 ; \mathrm{p}=0.092)$, and self efficacy $(\mathrm{OR}=0.14 ; 95 \% \mathrm{CI}=0.01$ to $0.26 ; \mathrm{p}=0.029)$. Self preventive care was indirectly associated with perceived severity, attitude, family support, and cues to action.

Conclusion: Self preventive care directly increases with perceived threat, perceived benefit, and self efficacy, and is indirectly associated with perceived severity, attitude, family support, and cues to action.
\end{abstract}

Keywords: type 2 diabetes mellitus, self preventive care, Health Belief Model

\section{Correspondence:}

Ummy Prasetyowati. Masters Program in Public Health, Universitas Sebelas Maret, Jl. Ir. Sutami 36 A, Surakarta 57126, Central Java. Email: ummyprasetyowati@gmail.com.

Mobile:+6281227225939.

\section{BACKGROUND}

$\overline{\text { The percentage of deaths due to diabetes }}$ mellitus in 2015 is the second highest disease in Indonesia after Sri Lanka for Southeast Asia (International Diabetic Ferderation, 2015). The number of people with diabetes mellitus in the world reached 422 million people including one in three adults over 18 years of age who are overweight (WHO, 2016).

According to International Diabetic Ferderation (IDF) (2017), Indonesia is the 7 th country with DM patients of 10 million after China, India and the United States,
Brazil, Russia, Mexico and diabetes complications is the third leading cause of death in Indonesia.

Diabetes mellitus is the second largest non-communicable disease in Central Java, which is $16.42 \%$ (Central Java Provincial Health Office, 2015). Dr. Moewardi hospital is one of the largest referral hospitals in Central Java located in of Surakarta.

Every year, patients with diabetes mellitus have increase, data on the number of patients with type $2 \mathrm{DM}$ inpatients in 2016 was 2,882 patients and outpatients were about 5,763. In 2017, type 2 DM 
patients from January to October 2017, the number of inpatients was 2,399 patients and outpatients were 3,857 patients (Medical record of Dr. Moewardi hospital, 2017).

DM disease progresses slowly and progressively so there is no early detection because of the clinical features experienced by patients such as trias diabetes mellitus, ie polyuria (frequent urination), drinking and eating lots. Diabetes control efforts aimed at preventing microvascular and macrovascular complications.

According to Perkeni (2015), complications from DM can be minimized by controlling the four pillars to support the improvement of quality of life that is education, food planning, sports, and treatment planning. Self-care supports the management of diabetes mellitus health programs, because DM requires ongoing medical supervision and self-care education in patients (Rembang et al., 2017).

The goal of DM treatment will be successful if diabetes management is performed on the patient's ability to initiate and act independently through self-care activities. The ability and habits of DM patients in proper self-care will significantly affect productivity and quality of life (Rantung et al., 2015).

The purpose of this study is to find out the health belief model with self-care behavior in patients with type 2 diabetes in Dr.MoewardiHospital, Surakarta.

\section{SUBJECTS AND METHOD \\ 1. Study Design \\ This was an analytic observational study with a cross sectional design. The study was conducted at Dr. Moewardi hospital, Sura- karta, Central Java.}

\section{Population and Samples}

The target population in the study was all patients of Type 2 DM in Dr. Moewardi Hospital, Surakarta in the period of March to April 2018. A sample of 200 patients was selected for this study by total sampling.

\section{Study Variables}

The independent variables in this study are the perception of severity, perception of vulnerability, perception of threat, perception of benefits, cues of action, self-efficacy, attitude, and family support. The dependent variable in this study is self-care.

\section{Operational Definition of Variables}

Perceived severity was defined as the feeling or perception of the severity of diabetes mellitus. If DM is not treated properly, it will cause the illness worse. The data was measured by questionnaire. The measurement scale was continuous, but for the purpose of data analysis, it was transformed into dichotomous.

Perceptions of vulnerability were defined as views or perceptions of a person about the risk of vulnerability itself about diabetes mellitus. The data were measured by questionnaire. The measurement scale was continuous, but for the purpose of data analysis, it was transformed into dichotomous.

Perceptions of threat were defined as the feelings or perceptions of a person which are the result of not taking any precautions or healing. The data were measured by questionnaire. The measurement scale was continuous, but for the purpose of data analysis, it was transformed into dichotomous.

Perceived benefit was defined as person's feelings or perceptions about perceivedbenefits in performing self-care behavior. The data were measured by questionnaire. The measurement scale was continuous, but for the purpose of data analysis, it was transformed into dichotomous.

Cues to action were media, people, or events that drive people to change the behavior in the treatment of diabetes mellitus. The data were measured by question- 
naire. The measurement scale was continuous, but for the purpose of data analysis, it was transformed into dichotomous.

Self-efficacy was defined as one's belief in doing self-care behavior of diabetes melitus. The data were measured by questionnaire. The measurement scale was continuous, but for the purpose of data analysis, it was transformed into dichotomous.

Attitude was defined as the tendency of a person in doing or responding to selfcare behavior diabetes mellitus. The data were measured by questionnaire. The measurement scale was continuous, but for the purpose of data analysis, it was transformed into dichotomous.

Family support was defined as a familyencouragement that affects self-care behavior of diabetes mellitus that includes emotional, financial, instrumental, and information support. The data were measured by questionnaire. The measurement scale was continuous, but for the purpose of data analysis, it was transformed into dichotomous.

Self-care behavior was defined as a self-care behavior of diabetes mellitus patients consisting of monitoring blood sugar, maintaining diet, regular exercise, having adequate rest, not smoking, and avoiding stress. The data were measured by questionnaire. The measurement scale was continuous, but for the purpose of data analysis, it was transformed into dichotomous.

\section{Data Analysis}

Univariate analysis aims to explain and describe the characteristics of each research variable based on primary and secondary data. Bivariate analysis was done to study self-care relationship with the independent variable by using chi square test and calculation of odds ratio (OR) with level of trust (CI) equal to $95 \%$. The data analysis was done using path analysis to know the direct or indirect influence of variable.

\section{Research Ethics}

The research ethics of this study include informed consent, anonymity, confidentiality and ethical clearance. The ethical clearance in the study was conducted at Dr. Moewardihospital Surakarta with number: 450/ IV/ HREC/ 2018.

\section{RESULTS}

1. Study Subjects Characteristics The frequency distribution of study subject characteristics is described in Table 1.

Table1. Subjects Distribution

\begin{tabular}{lcc}
\hline \multicolumn{1}{c}{ Characteristics } & n & \% \\
\hline Education & & \\
\hline$<$ SHS & 98 & 49 \\
>SHS & 102 & 51 \\
Perceived severity & & \\
Low & 93 & 46.5 \\
High & 107 & 53.5 \\
Perceived vulnerability & & \\
Low & 75 & 37.5 \\
High & 125 & 62.5 \\
Perceived threat & & \\
Low & 62 & 31 \\
High & 138 & 69 \\
Perceived benefit & & \\
Low & 88 & 44 \\
High & 112 & 112 \\
Cues to Action & & \\
Low & 72 & 36 \\
High & 128 & 64 \\
Self-efficacy & & \\
Weak & 82 & 41 \\
Strong & 118 & 59 \\
Attitude & & \\
Low & 35 & 17.5 \\
High & 165 & 82.5 \\
Family support & & \\
Low & 75 & 37.5 \\
High & 125 & 62.5 \\
Self-care & & \\
Low & 98 & 49 \\
High & 102 & 51 \\
\hline & & \\
& &
\end{tabular}

\section{Path Analysis}


Path analysis model results the number of observed variables were 9 , including 3 endogenous variables and 6 exogenous variables. Degree of freedom $(\mathrm{df})=28$ shows that the path analysis is over identified. Path analysis model was depicted in Figure 1.

Table 2 shows a positive association between perceived threat and preventive care among patients with type 2 diabetes mellitus. Strong perceived increased preventive care in patients with type $2 \mathrm{DM}(\mathrm{b}=$ 3.21; $95 \% \mathrm{CI}=1.99$ to 4.43 ; $\mathrm{p}<0.001$ ).
There was a positive association between perceived benefit and preventive care among patients with type 2 diabetes mellitus. Strong perceived benefit increased preventive care in patients with type $2 \mathrm{DM}(\mathrm{b}=$ $0.68 ; 95 \% \mathrm{CI}=-1.11$ to $1.47 ; \mathrm{p}=0.092)$.

There was a positive association between self-efficacy and preventive care among patients with type 2 diabetes mellitus. Strong self-efficacy increased preventive care in patients with type $2 \mathrm{DM}(\mathrm{b}=$ $0.14 ; 95 \% \mathrm{CI}=0.014$ to $0.26 ; \mathrm{p}=0.029$ ).

Tabel 2. Path analysis results of factors associated with self care behavior in type 2 diabetes mellitus

\begin{tabular}{|c|c|c|c|c|c|c|}
\hline \multirow{2}{*}{$\begin{array}{l}\text { Dependent } \\
\text { variable }\end{array}$} & & \multirow[t]{2}{*}{ Independent variable } & \multirow[t]{2}{*}{$\mathbf{b}$} & \multicolumn{2}{|c|}{ 95\% CI } & \multirow[b]{2}{*}{$\mathbf{p}$} \\
\hline & & & & $\begin{array}{l}\text { Lower } \\
\text { Limit }\end{array}$ & $\begin{array}{l}\text { Upper } \\
\text { Limit }\end{array}$ & \\
\hline \multicolumn{7}{|l|}{ Direct Effect } \\
\hline Self care behavior & $\leftarrow$ & Perceived threat & 3.21 & 1.98 & 4.43 & $<0.001$ \\
\hline Self care behavior & $\leftarrow$ & Perceived benefit & 0.68 & -0.11 & 1.47 & 0.092 \\
\hline Self care behavior & $\leftarrow$ & Self efficacy & 0.14 & 0.01 & 0.26 & 0.029 \\
\hline \multicolumn{7}{|l|}{ Indirect Effect } \\
\hline Perceived threat & $\leftarrow$ & Perceived severity & 1.82 & 0.94 & 2.70 & $<0.001$ \\
\hline Perceived threat & $\leftarrow$ & Cues to action & 2.05 & 1.24 & 2.86 & $<0.001$ \\
\hline Perceived threat & $\leftarrow$ & Perceived threat & 2.16 & 1.50 & 2.84 & $<0.001$ \\
\hline Perceived benefit & $\leftarrow$ & Attitude & 2.16 & 1.23 & 3.10 & $<0.001$ \\
\hline Attitude & $\leftarrow$ & Perceived susceptibility & 1.82 & 0.97 & 2.68 & $<0.001$ \\
\hline $\begin{array}{l}\text { Cues to action } \\
\mathrm{N} \text { observasi }=200 \\
\text { Log likelihood }=-60\end{array}$ & $\leftarrow$ & Family support & 1.11 & 0.50 & 1.71 & $<0.001$ \\
\hline
\end{tabular}

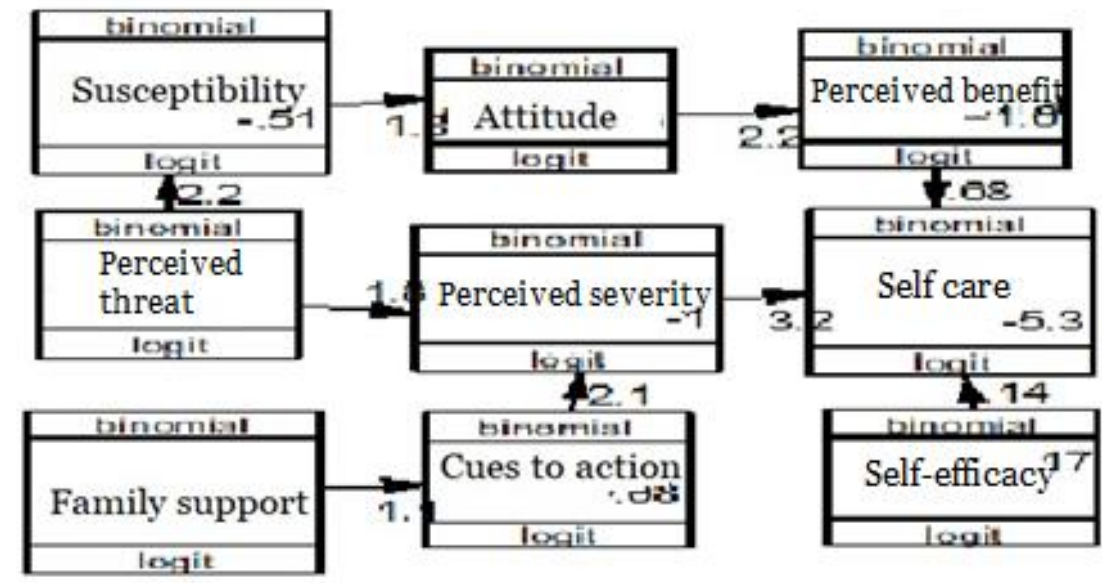

Figure 1. Structural Model of Path Analysis with Estimate 
Journal of Health Promotion and Behavior (2018), 3(2): 86-93

https://doi.org/10.26911/thejhpb.2018.03.02.01

There was a positive association between perceived severity and perceived threat. Strong perceived severity increased perceived threat $(\mathrm{b}=1.82 ; 95 \% \mathrm{CI}=0.94$ to 3.70 ; $\mathrm{p}<0.001$ ).

There was a positive association between cues to action and perceived threat. High cues to action increased perceived threat $(\mathrm{b}=2.05 ; 95 \% \mathrm{CI}=1.240$ to 2.863; $\mathrm{p}<0.001$ ).

There was a positive association between perceived severity and perceived susceptibility. Strong perceived severity increased perceived threat $(b=2.17 ; 95 \%$ $\mathrm{CI}=1.50$ to $2.84 ; \mathrm{p}<0.001$ ).

There was a positive association between attitude and perceived benefits. Positive attitude increased perceived benefit $(b=2.16 ; 95 \% \quad C I=1.23$ to 3.10 ; $\mathrm{p}<0.001)$.

There was a positive association between perceived susceptibility and preventive care among patients with type 2 diabetes mellitus. Strong perceived susceptibility increased preventive care in patients with type $2 \mathrm{DM}(\mathrm{b}=1.82 ; 95 \% \mathrm{CI}=0.968$ to 2.680; $\mathrm{p}<0.001$ )

There was a positive association between family support and cues to action. Strong family support increased cues to action $(\mathrm{b}=1.11 ; 95 \% \mathrm{CI}=0.50$ to $1.71 ; \mathrm{p}$ $<0.001$ )

\section{DISCUSSIONS}

\section{The effect of perceived threat on DM 2 self care}

This study showed that there was a positive effect of perceived threat on preventive care in patients with type $2 \mathrm{DM}$, and it was statistically significant. The result of analysis in this study showed that people with strong perceived threat increased preventive care in patients with type $2 \mathrm{DM}$.

This was due to the first judgment felt from the perceived threat of risk, which triggered the people to assume that illness or pain was a threat. When people have a high threat, there would be a preventive behavior to prevent the severe disease or complications (Shabibi et al., 2017)

\section{The effect of perceived benefit on DM self care}

This study showed that there was a positive effect of perceived benefit on preventive care in patients with type $2 \mathrm{DM}$. The result of analysis in this study showed that people with high perceived benefit increased preventive care in patients with type $2 \mathrm{DM}$. Health behavior was influenced by perceived benefits. The benefit refers to the individual assessment of benefits in reducing the risk of complications. If someone believed that a particular action could reduce the susceptibility to the problem and decrease the severity, they would engage in the preventive behavior. For example, a person who believed that reducing salt could help in managing and reducing the risk of hypertension would be more likely to obey than someone who did not believe in the benefit of salt (Onoruoiza et al., 2015).

\section{The effect of self efficacy on DM 2 self care}

This study showed that there was a positive effect of self efficacy on preventive care in patients with type $2 \mathrm{DM}$. The result of analysis in this study showed thatpeople with high self efficacy would increase DM 2self-care. This explained that someone who has good self-efficacy would be more obedient to the preventive behavior.

Individuals with strong self-efficacy have great expectations for the success of goal achievement, whereas individuals with low self efficacy have doubts in achieving their goals. DM patients with behavioral changes were necessary to achieve the goal of DM management such as sugar levels in normal limits. 
Self-efficacy was one of the key factors for achieving behavioral change. Self-efficacy was the patient's belief in acting and behaving which in accordance with the expectations of patients and health personnel. Self-efficacy can affected behavioral change by influencing a person's thinking, self-motivation, and action (Rahman and Sukmarini, 2017).

A study by Masoompour et al. (2017), stated that self-efficacy was related to selfcare behavior. Self-efficacy was the first element of DM patients in making health behavior changes and controlling blood sugar levels. People who have high selfefficacy also have better self-care behavior.

\section{The effect of perceived severity on DM 2 self care.}

This study showed that there was an indirect effect of perceived severity on preventive care in patients with type $2 \mathrm{DM}$ through perceived threat. The results of analysis showed that people with strong perceived severity would increase perceived threat and improve DM 2 self-care.

A person who felt that pain or severity would became severe if she/he did not make any prevention and felt that it was a threat that can affect the psychological, she/he would increase the prevention efforts and became more obedient (Kugbey et al., 2017).

According to a study by Vazini and Barati (2014), perceived threats (vulnerability \& severity) affected self-care behavior which mean that with the enhancement of perceived threat, self-care was also increased, perceived threats including social relations disturbances and disease severity.

\section{The effect of cues to action on perceived threat}

This study showed that there was an indirect effect of cues to action on DM 2 self-caret hrough perceived threat. The results of analysis showed that people with high cue to action would increase the perceived threat and improved DM 2 selfcare.

Cues to action was needed to encourage individual involvement in health promotion. Cue to action can be external and internal. Physiological cues such as pain and symptoms which belong to internal cues. External cues including media and events that can change health behavior(Onoruoiza, Musa, Umar, \& Kunle, 2015).

A study byBlake (2017)stated thatcues to actionwere related toDM 2 self care $(\mathrm{p}=$ o.004) with the availability of information, media, and health services, it can lead to changes in behavior to improve health status.

\section{The effect of perceived severity on perceived susceptibility}

This study showed that there was an indirect effect of perceived severity on preventive care in patients with type $2 \mathrm{DM}$ through perceived susceptibility.

The results of path analysis showed that people with high perceived severity would increase perceived susceptibility. This showed that those two perceptions were interrelated because perceived severity and perceived susceptibility could affect perceived threats that could increase DM 2 self-care (Kiti, 2018).

\section{The effect of attitude on perceived benefit}

This study showed that there was an indirect effect of attitude on DM 2 self-care through perceived benefit. The results of analysis showed that people with good attitude would increase perceived benefit which can improve DM 2 self-care. Behavior was influenced by perceived benefit in the form of action. Actions arised from the perceived benefits of individual assessment in reducing the risk of disease (Onoruoiza et al., 2015). 
Journal of Health Promotion and Behavior (2018), 3(2): 86-93

https://doi.org/10.26911/thejhpb.2018.03.02.01

Attitudes affected the perceived benefits that could change health behavior. If a person has a good attitude and high perceived benefit, then the DM 2 self-care was also increased (Kumaat, 2017).

\section{The effect of perceived suscepti- bility on attitude}

This study showed that there was an indirect effect of perceived susceptibility on DM 2 self-care through attitude and perceived. The results of analysis showed that people with high perceived susceptibility would have high self-care.

A person with high perceived susceptibility felt that he or she was susceptible to illness or complications if he/she did not change his/her behavior. Perceived susceptibility was a subjective perception of a person from contracting to a disease that could affect the prevention of disease which influenced by a person's readiness to act (Onoruoiza et al., 2015).

Perceived susceptibility was one of the important factors in influencing behavioral and attitude changes. Susceptibility was an effective factor in behavioral changes among diabetic patients in self-care, patients should know that susceptibility might affect the susceptibility to complications of diabetes mellitus (Khorsandi et al., 2017).

\section{The effect of family support on cues to action}

This study showed that there was an indirect effect of family support on DM 2 selfcaret hrough perceived benefit. The result of analysis showed that people with high family support would increase cues to action in order to change their health behaviors. One of the pillars in supporting behavioral changes was family. Family was the main support system for problems that occur in family members. In general, people who received the attention and help from the nearest person or group of people tend to follow medical advice than those who did not get support at all. (Prawirasatra, Wahyudi, \& Nugraheni, 2017).

Support provided by families to family members who have DM could improve the quality of life. With the enhancement of DM patients' quality of life, it could increase self-confidence and DM patients could survive in suffering from DM (Mirza, 2017). DM 2 self care was directly affected by perceived threat, perceived benefits and self efficacy, and DM 2 self care was indirectly affected by perceived severity, cues to action, attitudes, perceived susceptibility, and family support.

\section{REFERENCES}

Blake H (2017). Health beliefs predict selfcare practices and glycaemic control in Malaysian patients with insulintreated diabetes. Health Beliefs Predict Self-Care Practices And Glycaemic Control In Malaysian Patients With Insulin-Treated Diabetes: A. Malaysian Journal Public Health.

Dinas Kesehatan Provinsi Jateng. (2015). Provinsi Jawa Tengah Tahun 2015, 151.

International Diabetes Federation. (2017). IDF Diabetes Atlas 8th Edition. International Diabetes Federation. https://doi.org/10.1289/image.ehp.v119.io 3 .

(2015). IDF Diabetes Atlas 7th edition.https://doi.org/10.1289/image.e hp.v119.io3.

Khorsandi M, Fekrizadeh Z, Roozbahani N, Press D (2017). Investigation of the effect of education based on the health belief model on the adoption of hypertension-controlling behaviors in the elderly. Clinical Interventions in Aging, 12, 233-240. https://doi.org/10.2147/CIA.S117142.

Kiti Y (2018). Elderly diabetes patients health beliefs about care and,15(1), 
27-31. https://doi.org/10.14687/jhs.v15i1.4903.

Kugbey N, Oppong Asante K, Adulai K (2017). Illness perception, diabetes knowledge and self-care practices among type-2 diabetes patients: A cross-sectional study. BMC Research Notes, 10(1), 1-7. https://doi.org/10.1186/s13104-017-2707-5.

Kumaat LT (2017). Gambaran Pengetahuan Dan Sikap Penderita Diabetes Melitus (Dm) Di Wilayah Kerja Puskesmas Tinoor, 5(November).

Masoompour M, Tirgari B, Ghazanfari Z (2017). The Relationship between Health Behaviors in Diabetic Patients. Evidence Based Care Journal, 51: 1625. https://doi.org/10.22038/EBCJ.2017.24826.1551

Mirza R (2017). Memaksimalkan Dukungan Keluarga Guna Meningkatkan Kualitas Hidup Pasien Diabetes Mellitus. Jurnal JUMANTIK, 2Dm.

Onoruoiza SI, Musa A, Umar BD, Kunle Y S (2015). Using Health Beliefs Model as an Intervention to Non Compliance with Hypertension Information among Hypertensive Patient. Journal of Humanities And Social Science, 20(9), 11-16. https://doi.org/10.9790/0837-20951116.

PERKENI (2015). Konsensus Pengendalian dan Pencegahan Diabetes Melitus Tipe 2 di Indonesia 2015. Perkeni. https://doi.org/10.1017/CBO9781107415324.004.

Prawirasatra WA, Wahyudi F, Nugraheni A (2017). Hubungan Dukungan Keluarga Terhadap Kepatuhan Pasien Dalam Menjalankan 4 Pilar Pengelolaan Diabetes Melitus Tipe 2 Di Puskesmas Rowosari. Jurnal Kedokteran Dipone- goro, 6(2), 1341-1360.

Rahman HF, Sukmarini L (2017). Efikasi Diri, Kepatuhan, dan Kualitas Hidup Pasien Diabetes Melitus Tipe 2 (Self Efficacy, Adherence, and Quality of Life of Patients with Type 2 Diabetes). E-Jurnal Pustaka Kesehatan, 5, 108113 .

Rantung J, Yetti K, Herawati T (2015). Hubungan self-care dengan kualitas hidup pasien diabetes melitus (DM) di Persatuan Diabetes Indonesia (Persadia) cabang Cimahi.Jurnal Skolastik Keperawatan, 1(1), 38-51.

Rekamedik RSUD Dr. Moewardi Surakarta. 2017. Surakarta.

Rembang VP, Katuuk ME, Malara R (2017). Hubungan Dukungan Sosial Dan Motivasi Dengan Perawatan Mandiri Pada Pasien Diabetes Dalam Rsud Mokopido Toli-Toli, 5.

Shabibi P, Sadegh M, Zavareh A, Sayehmiri, K, Qorbani M, Rastegarimehr B (2017). Electronic Physician (ISSN: 2008-5842), (December), 5960-5968.

Vazini H, Barati M (2014). The Health Belief Model and Self-Care Behaviors among Type 2 Diabetic Patients.Iranian Journal of Diabetes And Obesity, 6(3), 107-113.

World Health Organization. (2016). Diabetes Fakta dan Angka. Diabetes Di Dunia. Retrieved from https://www.google.com/url?sa $=t \& r c t=j \& q=\& e s r c$ $=$ s\&source $=$ web\&cd $=1 \& c a d=$ rja\&uact $=8 \&$ ved $=$ oahUKEwi8gs2Cv4LZAhXM s48KHQCuA9oQFggwMAA\&url=http \%3A\%2F\%2Fwww.searo.who.int\%2Fi ndonesia\%2Ftopics\%2F8-whd2016diabetes-facts-and-numbers-indonesian.pdf\&usg=AOvVawok4OGXSwG UF. 